\title{
A CSELEKVŐKÉPTELENEK VÉDELME - A FRANCIA, AZ OSZTRÁK ÉS A MAGYAR JOG ÖSSZEHASONLÍTÓ ELEMZÉSE $^{* *}$
}

https://doi.org/10.51783/ajt.2021.2.02

A kiskorúakra és a cselekvőképtelen nagykorúakra vonatkozó jogi szabályozás bemutatására a francia, az osztrák és a magyar jogrendszer összehasonlító elemzésén keresztül kerül sor. Az elemzés a cselekvőképességre és a gondnokságra vonatkozó szabályokat a Code Civil és az ABGB megalkotásának időszakától kezdődően a hatályos szabályozásig tárgyalja. A gyámságra és a gondnokságra vonatkozó jogintézmények bemutatása során figyelemmel van az állami szerepvállalás történeti alakulására, a hivatásos gondnoksági rendszer létrejöttére és szerepére, az intézetben történö elhelyezések növekvő számadataira. A gyámsági és gondnoksági feladatok megoldásában valamennyi vizsgált jogrendszerben szerepet kapott a szélesebb értelemben vett család, de a szabályozás eltérő volt abban a tekintetben, hogy csak a felügyeletet utalta bírósági hatáskörbe (francia megoldás), vagy maga a gyámi szerepkör ellátása valósult meg bíróságokon keresztül (osztrák jog) vagy a közigazgatási szervezetrendszer keretében (magyar jog).

A jogfejlődés szoros összefüggésben volt a változó társadalmi-gazdasági körülményekkel, az iparosodás során végbement demográfiai változásokkal, a legújabb korban pedig szembenéz az egészségügy fejlődésével is. Az apai hatalomra, a szülö és a gyermek közötti viszonyra, a házastársak egymás közötti kapcsolatára, a házasságon kívül született gyermekek megítélésére vonatkozó szabályok bemutatása tükrözi a család fogalmának átalakulását, a gyermekek helyzetét és a nök megváltozott szerepkörét. A cselekvőképtelen nagykorúak vonatkozásában az egyes jogrendszerekben kialakuló gondnoksági szabályok különböztek aszerint, hogy milyen fokú cselekvőképességet ismertek, később pedig menynyiben valósították meg a gondnokság kiváltására alkalmas támogatási formákat. A cselekvőképtelen személyekre és a gondnokságra, gyámságra vonatkozóan a Code Civil és az ABGB rendelkezéseinek bemutatására kerül sor, figyelembe véve e szabályok későbbi változását is, összehasonlításban a XIX. századi magyar jogfejlödés eredményeivel, a XX. század elején megalkotott magyar magánjogi tervezetek szabályaival, valamint az 1959es, a 2009-es és a 2013-as magyar polgári törvénykönyvvel.

* Osztályvezető, Alapvető Jogok Biztosának Hivatala, Nemzeti Megelőző Mechanizmus Főosztály, 1055 Budapest, Falk Miksa u.9-11. E-mail: izso.krisztina@ajbh.hu.

** A cikk nem tekinthető sem az alapvető jogok biztosa, sem az Alapvető Jogok Biztosa Hivatalának hivatalos állásfoglalásaként. 


\section{BEVEZETÉS}

A jogrendszer a társadalomnak azokat a tagjait, akik valamilyen okból (testi vagy mentális fogyatékosság, gyermekkor) sérülékenyek, minden időben védeni próbálta oly módon, hogy a rájuk való odafigyelést más személyek feladatává tette, és a más személy közbenjárásával történő döntéshozatalt vagy eljárást garanciákkal igyekezett biztosítani.

A cselekvőképtelen személyekről történő gondoskodás a család és a tágabb közösség feladata egyaránt, amihez az állami szervezetrendszernek segítséget kell adnia. Az állami szerepvállalás történetileg összefüggött a demográfiai és gazdasági változásokkal, és a gyámügyi, valamint a gondnokságra vonatkozó szabályozásban tükröződött.

A cselekvőképtelenek - különösen a kiskorúak - védelméről szóló szabályok részben a családjogban gyökereznek, mert a jogszabályok a támogatás feladatát elsődlegesen a természetes módon hozzájuk legközelebb állókra, a szülőkre ruházzák. A cselekvőképességre és a gondnokságra vonatkozó szabályokban valójában a jogrendszernek a családról alkotott képe rajzolódik ki, ezek a szabályok a gyermek és a szülők (az apa és a gyermek, az anya és a gyermek), illetve a szülők egymás közötti viszonyának jogi megjelenését jelentik. A XXI. századi „kis család” fogalmával szemben a XIX. században megjelenő francia „családtanács” intézmény vagy a magyar jogban is ismert „családi tanács” a rokonok szélesebb körét magában foglaló, nagyobb családot jelentette.

A kiskorúakra vonatkozó szabályok a család felfogásának megváltozásán túl jelzik a gazdasági viszonyok átalakulását is (a kapitalizálódó világban a gyermek is munkavállalóvá válik), a XXI. századi legújabb fejlődésben pedig az egészégügy kapcsán a nem vagyoni természetü, a személyhez kapcsolódó döntéshozatal eltérő szabályozásának szükségessége jelent meg.

A cselekvőképesség történeti bemutatása kapcsán tárgyalni kell a nők helyzetét. A rájuk vonatkozó szabályozás (beleértve a prostitúció szabályozását is) szintén a megváltozó gazdasági-társadalmi viszonyokat tükrözte.

A segítségre szoruló felnőttek számára is sokszor a hozzátartozót jelölik ki mint a szükséges támogatást nyújtó személyt, a gondokolt és a gondnok között ilyenkor családjogi kapcsolat is fennáll. Sok esetben nem a hozzátartozó, hanem hivatásos gondnok kerül kinevezésre, és a hivatásos gondnok gyakran több, olykor olyan sok személy felett látja el a gondnoki feladatokat, hogy a személyes kapcsolattartás lehetőségei korlátozódnak.

A cselekvőképtelenek mellé kijelölt segítők (szülők, gyám, gondnok) mellett a XIX. századtól megkezdődtek, és fokozódó ütemben növekedtek az intézményi elhelyezések. Magyarországon és Ausztriában árvaházak nyíltak, ezeknek az intézményeknek a vezetői gondnoki funkciót is betöltöttek. Franciaországban az vált jellemzővé, hogy a családtagok a mentális betegséggel élő hozzátartozóik intézményi elhelyezését kérték. Ilyen tartós elhelyezést biztosító intézményeket a kiegyezést követően Magyarországon is létesítettek.

A Központi Statisztikai Hivatal adatai szerint Magyarországon 2019-ben 8277-en éltek pszichiátriai betegek otthonában, 14 465-en fogyatékossággal élők otthoná- 
ban. ${ }^{1}$ Az ENSZ Fogyatékossággal Élő Személyek Bizottsága (CRPD Bizottság) által közzétett adatok szerint 2017-ben Magyarországon a fogyatékossággal élők bentlakásos szociális intézményében élők 5,9\%-a (744 személy) kiskorú volt. ${ }^{2}$ Különleges szükségletű (fogyatékossággal élő vagy három év alatti gyermekek) ellátását biztosító nevelőszülők száma 2019-ben 1135 volt, ${ }^{3}$,és a gyermekotthonokban is élnek ilyen szükségletü kiskorúak.

Az Alapvető Jogok Biztosa által 2016-ban közzétett jelentés ${ }^{4}$ alapján a Kormányhivatalok adatai szerint a gondnokoltak száma 49053 fő volt, akik közül több mint 17000 gondnokoltat 747 hivatásos gondnok képviselt, a nem hivatásos gondnokok száma kb. 28800 fő volt. A kirendelt hivatásos támogatók száma 44, a kirendelt nem hivatásos támogatók száma 26 volt.

Magyarország 2007. március 30-án írta alá az ENSZ Közgyülése által 2006. december 13-án elfogadott, a Fogyatékossággal élő személyek jogairól szóló Egyezményt (CRPD) és az ahhoz kapcsolódó Fakultatív Jegyzőkönyvet, az Egyezmény 2008. május 3-án lépett hatályba. A CRPD új szemléletet közvetít: a fogyatékossággal élő személyeket nem védeni kell a jogaik korlátozása útján, ők a szükséges támogatások és az észszerű alkalmazkodás biztosításával személyesen képesek gyakorolni a jogaikat (ún. szociális modell). ${ }^{5} \mathrm{Az}$ Egyezmény cselekvőképességről szóló 12. cikk (2) bekezdése úgy rendelkezik, hogy „a fogyatékossággal élő személyeket az élet minden területén másokkal azonos alapon megilleti a cselekvőképesség”. Az Egyezmény 19. cikke szól arról, hogy a fogyatékossággal élő személyeknek egyenlő joguk van a közösségben való élethez, a lakóhelyük megválasztására, a közösségi támogató szolgálathoz.

A nemzetközi egyezményben foglaltak szükségessé teszik a meglévő cselekvőképességi szabályozás átgondolását, a gondnoksági rendszer átalakítását. Az új szabályoknak a szerves fejlödés keretében történő kialakítása, a dogmatikai rendszerbe foglalása nem nélkülözheti a történeti szabályozás ismeretét és a más országok szabályaival való összehasonlítást.

A jelen írás célja feltérképezni azt, hogy a XIX. századi magánjogi kodifikációk létrejötte óta hogyan változtak a cselekvőképtelenekre vonatkozó szabályok a vizsgált jogrendszerekben. A XIX. század elejének két nagy polgári törvénykönyve, a francia Code Civil és az osztrák ABGB cselekvőképtelenekre vonatkozó szabályainak történeti fejlődésükben való bemutatására és az ugyanebben a korban Magyarországon hatályban lévő rendelkezésekkel összevetésére kerül sor. A Code Civil és az ABGB szabályainak a magyar joggal együttes tárgyalását az indokolja, hogy a francia forradalom eszméi új társadalmi felfogást fejeztek ki egész Európában, az osztrák jog pedig nagy hatással volt a magyar jogfejlődésre. Az egyes jogszabályi rendelkezé-

1 Lásd: $h t t p: / / w w w . k s h . h w / d o c s / h u n / x s t a d a t / x s t a d a t \_e v e s / i \_f s i 001 . h t m l$.

2 Annex to State party report (30 April 2018), https://tbinternet.ohchr.org/layouts/15/treatybodyexternaVTBSearch.aspx? Lang $=$ en\&TreatyID $=4 \&$ DocTypeID $=29$.

3 Lásd: http://statinfo.ksh.hw/Statinfo/haViewer.jsp?wcf9bb77c59=x.

4 AJB-2709/2016. számú jelentés.

5 GURBAI Sándor: A gondnokság alá helyezett személyek választójoga a nemzetközi jog, az európai regionális jog és a komparatív közjog tükrében (Budapest: Pázmány 2016) 13. 
sek megértéséhez és összehasonlíthatóságához szükség van a különböző országok eltérő fejlődésének, a rendelkezések társadalmi-gazdasági hátterének feltárására is, beleértve a kódexek keletkezéstörténetének rövid felvázolását.

A cselekvőképtelenekre vonatkozó szabályok áttekintése megpróbál fogalmi tisztaságot is közvetíteni az apai hatalom, gyámság, gondnokság - egyes országokban sokszor más és más értelemben használt, és többféle kifejezéssel is illetett - kategóriái között.

\section{A XIX. SZÁZAD ELEJÉNEK KÉT POLGÁRI TÖRVÉNYKÖNYVE ÉS A MEGKÉSETT MAGYAR JOGFEJLŐDÉS}

A francia Code Civil és az osztrák ABGB ugyanabban a történelmi korszakban született meg. Keletkezésükre hatottak az egyes területeken irányadó szokásjogok, a római jog, a középkori filozófiák tanításai, a természetjogi elvek és a jogtudományi kutatások eredményei. A törvénykönyvek a nemzeti jogfejlödésükbe beágyazottan, az egyes országok történeti sajátosságainak megfelelően jöttek létre. A történeti fejlődés különbözőségéből adódóan a római jogi hatások is más-más módon érték a két jogrendszert.

\subsection{A RÓMAI JOG ÉS A COUTUME-ÖK HATÁSA A CODE CIVILRE}

A Code Civil megalkotását megelőző időszakban Franciaországot egyaránt jellemezte az egymástól is különböző, majd egységesedést mutató ${ }^{6}$ coutume-ök joga a déli területeken, és a széttagolt, több mint háromszáz törvénykönyvet jelentő írott jog területe, amelyet a királyi rendeletek szintén megpróbáltak az egységesítés irányába terelni. ${ }^{7}$ A jog egységesítését megelőzően jellemző volt, hogy a különböző életviszonyokat sokszor más-más eredetű (kánonjog, helyi coutume, római jog) szabályoknak vetették alá. ${ }^{8}$ A római jog recepciója az írott jog területén sajátos módon ment végbe: hasonlóan, mint a közösség által elfogadott coutume nyert elfogadást. ${ }^{9}$ Bizonyos kérdésekben a római jogot a déli, a coutume-ök uralta területen is részlegesen alkalmazták, ha az elfogadott szokások nem adtak kielégítő szabályozást (különösen a szerződési jogban). ${ }^{10}$

A francia forradalmi jogalkotás a kétféle (római jog és coutume-ök) versengő jogterület közül a coutume-ök szabályaira épített - lényegében lerombolta az ezen kívüli jogot. ${ }^{11}$ Központi és önálló szerepet kapott a család: ez volt az a terület, ahol a legke-

6 Fr. Olivier-Martin: Histoire du droit français des origines à la Révolution (Montchrestien: Editions Domat 1948) 425.

7 Ph. SAGnAC: La législation civile de la Révolution française Essai d'histoire sociale (Paris: Hachette et Cle 1898) 2-3., https://doi.org/10.2307/2139795.

8 Jean Carbonnier : Droit civil, Introduction, les Personnes (Presses Universitaires de France) 66.

9 Olivier-Martin (6. lj.) 122. és 427.

10 Olivier-Martin (6. lj.) 427.

11 SAgnac (7 lj.) 14. és 305. 
vésbé tartották fontosnak a jogi beavatkozást, olyannyira, hogy az állami bíróságok helyett rokonokból álló tanács döntött a családhoz kapcsolódó vitás kérdésekben. ${ }^{12}$ A coutume-öket követve a forradalom idején alkotott jog már nem ismerte a teljes apai hatalmat. A coutome-ök jogában az apát és az anyát egyaránt megillette a „természetes gyámság”, ami - az egyes jogterületek szerinti különbségekkel a gyermek húsz-huszonöt éves koráig vagy házasságkötéséig tartott. ${ }^{13}$ A kódex az apai hatalom szabályait megváltoztatott formában visszaállította. ${ }^{14}$

A francia Code Civil a forradalmat követően született, de nem az adott kor pillanatnyi adottságait, hanem egy olyan hosszú folyamatot tükrözött, amely a megelöző századokban kialakult jogi szokásrendszert is magában foglalta. ${ }^{15} \mathrm{~A}$ francia köztársaság idején létrejött tervezetek alkotásában közremüködő szerzők, Cambécères, Tronchet javaslatai azt tükrözik, hogy a kodifikációk az egyes városok coutume-jei és a római jogi szabályok közül, a kiskorúak rendelkezési joga, végrendelkezési képessége tekintetében a legmegengedőbb szabályokat akarták a törvénykönyvbe foglalni, figyelve arra is, hogy ezek a rendelkezések a házasságban és azon kívül született gyermekekre egyformán vonatkozzanak. ${ }^{16}$

A francia forradalmi eszme hatása és jelentősége nem abban volt, hogy a deklarációkban megfogalmazódott, hanem valóban belül a társadalomban, az egyén életében voltak ennek a legfontosabb következményei.

A tervezetek a néhány évvel később megszületett Code Civil-re is hatással voltak. A XIX. század elejének kodifikációja révén a további hatások között meg kell említeni a természetjog mint a korábbi időszakban minden pozitív jog forrásának tekintett egyetemes törvény hatását. ${ }^{17} \mathrm{~A}$ forradalom korának tervezetében szerepelt, inkább filozófiai tartalmú, természetjogi gondolatokról szóló bevezető fejezet („Du droit et des lois”) mindazonáltal a hatályba lépett törvénykönyvből már kimaradt. ${ }^{18}$

\subsection{A SZOKÁSJOGOK ÉS A RÓMAI JOG ALKALMAZÁSA AZ OSZTRÁK POLGÁRI TÖRVÉNYKÖNYV LÉTREJÖTTÉIG}

Ausztriában a jogi partikularizmus időszakában az egyes tartományok egymástól eltérő szokásjogi rendszerében a római jog mint az alkalmazandó szubszidiárius jog volt jelen, majd lényegében beépült az alkalmazandó jogba oly módon, hogy fontos szerepet kapott mind az egyes tartományok jogkönyveinek, törvényeinek elkészí-

12 Sagnac (7. lj.) 305.

13 SAGnac (7. lj.) 2. és 302.

14 A Napóleon uralma alatt megszülető Code Civil ideológiájának jellemzését ld. HaRmatHy Attila: „Állam és Polgári jog” in: MEnyHÁRd Attila - VARGA István (szerk.): 350 éves az Eötvös Loránd Tudományegyetem Állam- és Jogtudományi Kara (Budapest: ELTE Eötvös 2018) II. 775-785.

15 René Demogue: Traité des obligations en general, Source des Obligations Tome 1. (Paris: Arthur Rousseau 1923) 1-2., Olivier-Martin (8. lj.) 426.

16 Conseil d'Etat. Discussion du Projet de Code Civil No 19 (Paris 1801).

17 Ambroise Colin - Henri CAPITANT : Cours élémentaire de droit civil français, Tome Premier (Paris: Dalloz 1947) 3.

${ }^{18}$ Carbonnier (8. lj.) 70. 
tése, mind pedig a tartományok jogainak egymáshoz való közelítése során, a jogegységesítés folyamatában. ${ }^{19}$

Az ABGB előmunkálatainak tekintett, 1766-ban elkészült, de hatályba nem lépett Codex Theresianus egy nagy terjedelmű, kazuisztikán alapuló, erős római jogi hatást tükröző törvénymű volt. ${ }^{20} \mathrm{~A}$ személyekre vonatkozó joganyagot és a családi joggal foglalkozó rendelkezéseket tartalmazta a II. József idején készült, 1786-ban hatályba lépett rész-ABGB, ami egyúttal azt is jelentette, hogy a római jog mint jogforrás többé nem volt alkalmazandó. ${ }^{21} \mathrm{Ez}$ a rész-törvénykönyv előrelépést jelentett a szülök és a gyermek közötti viszony szabályozása kapcsán abban, hogy a házasságon kívül született gyermek eltartásáról is rendelkezett oly módon, hogy a tartásra a feltételezett vagy az anya által megjelölt és bizonyított apa volt köteles, az anya jogállásának megfelelő mértékben. A házasságon kívüli gyermek mindkét szülői ágon örökölt. „Valódi” házasságon kívül született gyermeknek az minősült (de a „szükségesnek megfelelő" tartásra ő is jogosult volt), akinél a szülők valamelyike házas volt, vagy közöttük házassági tilalom állt fenn. Amennyiben a szülők egyike sem volt harmadik személlyel házas, vagy a gyermek érvénytelen házasságból származott különösen, ha az érvénytelenségi ok elhárítható lett volna - a gyermek lényegében a házasságból született gyermekkel egyenjogúnak számított. ${ }^{22} \mathrm{~A}$ rész-ABGB megszüntette a tékozlók gondnokságának jogintézményét is. ${ }^{23}$

A természetjog hatása az ugyanebben a korszakban születő osztrák kodifikáció tekintetében sem volt elhanyagolható. A Codex Theresianus létrejöttét követően felállt újabb törvényszerkesztő bizottság számára Mária Terézia már a „természetes méltányosság” szem előtt tartását írta elő, így a kodifikációt ez is befolyásolta, a római jog - már nem kötelező - figyelembevétele mellett. ${ }^{24}$

A római jog az ABGB őstervezetét jelentő Martini-tervezetnek is alapjául szolgált ${ }^{25}$, és a Code Civilt csupán néhány évvel követve, 1812. január 1-jén hatályba lépett Osztrák Polgári Törvénykönyv szerkezetében és a jogintézmények szabályaiban is tükrözött római jogi elveket. ${ }^{26}$

${ }^{19}$ Hamza Gábor: „Az osztrák magánjog fejlődése és kodifikációja a római jogi hagyomány tükrében” Acta Facultatis Politico-iuridicae Universitatis Budapestinensis I. 2013 63-78. 64-69.

${ }^{20}$ Hamza (19. lj.) 70., Helmut Kozıol - Rudolf Welser: Grundriss des bürgerlichen Rechts Band I. (Wien: Manzsche Verlags- und Universitätsbuchhandlung 2016) 10.

${ }^{21}$ Hamza (19. lj.) 71.

${ }^{22}$ Az 1786-os rész-ABGB szövege az interneten hozzáférhető: http://www.koeblergerhard.de/Fontes/JGB20070429-rund18800woerter.htm.

${ }^{23}$ Hamza (19. lj.) 71.

${ }^{24}$ Hamza (19. lj.) 70., Koziol-Welser (20. lj.) 10.

${ }^{25}$ Hamza (19. lj.) 71., Koziol-Welser (20. lj.) 10.

${ }^{26}$ Hamza (19. lj.) 71-73. 


\subsection{A XIX. SZÁZADI MAGYAR MAGÁNJOG ÉS A XX. SZÁZAD ELEJÉnEK POLGÁRI TÖRVÉNYKÖNYV TERVEZETEI}

A jogtörténeti irodalom szerint a magyar magánjognak Werbőczy Hármaskönyvében kifejlődött rendszere megmaradt, és lényegében ezen az alapon fejlődött tovább egészen 1848-ig. ${ }^{27} \mathrm{~A}$ XIX. századi reformmozgalmak elsődlegesen az ősiség eltörlésére irányultak, ami magában hordozta az öröklési jogi szabályok megalkotásának szükségességét, ezáltal egy polgári jogi kódex megalkotásának gondolatát is. ${ }^{28}$

1861-ben az Országbírói Értekezlet által megalkotott Ideiglenes Törvénykezési Szabályok az osztrák polgári törvénykönyv magyarországi alkalmazását követően újra magyar szabályozás életbe lépését jelentették. A bírói gyakorlatra, majd a századfordulót követően a magánjogi törvénytervezetek létrejöttére mindazonáltal továbbra is jelentős befolyást gyakoroltak az osztrák kódex szabályai.

Az 1877-es gyámságról szóló törvény a hiányos vagy tökéletlen család pótlását állami feladattá tette, és megfogalmazta az apai hatalomra, valamint az apai hatalom alatt nem álló (gyámság alá tartozó) kiskorúakra vonatkozó legfontosabb szabályokat. Az 1928-as Magánjogi Törvényjavaslat a gyámtörvény anyagi jogi szabályait teljes egészében felölelte (magánjogi jellegéből adódóan a közigazgatási jellegű szabályokat mellőzte, és törvénykönyv lévén szerkezeti változtatásokat is eszközölt), ${ }^{29}$ beemelte továbbá a bírói gyakorlat által megvalósított szabályokat is. ${ }^{30}$

A XX. század elején az első magyar polgári jogi kodifikáció tervezetek megalkotása során a szerkesztők a meglévő magyar bírói gyakorlat mellett áttekintették a nyugati társadalmak törvénykönyveinek rendelkezéseit (és tekintettel voltak ezek később történt módosításaira is). Emiatt a cselekvőképtelenekre vonatkozó szabályozás ismertetése során az osztrák és a francia kódex szabályai kapcsán - a korabeli magyar magánjog mellett - hivatkozom az egy évszázaddal később alkotott magyar tervezetekre is. Az összehasonlítás során ugyanakkor természetszerüleg tekintettel kell lenni a magyar fejlődés megkésettségére, arra, hogy ezek a tervezetek egy másik korszakban, és a saját történelmi adottságokból fakadóan is, eltérő társadalmi-gazdasági háttérben születtek.

${ }^{27}$ ILLÉs József : Bevezetés a magyar jog történetébe (Budapest: Grill 1930) 72.

${ }^{28}$ ILLÉs (27. lj.) 293.

${ }^{29}$ SuHAYDA János: A magyar polgári anyagi magánjog rendszere az Országbírói Értekezlet által megállapitott szabályokhoz és azóta a legújabb időig hozott törvényekhez (Budapest: Magyar Királyi Egyetemi Könyvnyomda 1874) 507.

30 ScHopf Kálmán: A hivatásos gyámság és a törvénytelen gyermek védelme (Budapest: Benkő 1912) 10. és SzeIBERLing Rezső: A kiskorúak és gondnokoltak külön joga a kapcsolatos jogszabályok keretében (Veszprém: Egyházmegyei Könyvnyomda 1932) 19. 
3. A CSELEKVÖKÉPTELENEK VÉDELMÉT SZOLGÁLÓ JOGINTÉZMÉNYEK AZ ELSŐ EURÓPAI KODIFIKÁCIÓKBAN ÉS A XIX. SZÁZAD MÁSODIK FELÉNEK MAGYAR MAGÁNJOGÁBAN (VALAMINT A XX. SZÁZAD ELEJÉNEK MAGÁNJOGI KÓDEXTERVEZETEIBEN)

\subsection{A CSELEKVÖKÉPTELEN SZEMÉLYEK}

A francia jogban cselekvőképtelenek voltak a kiskorúak, a bírósági határozattal ilyennek nyilvánított nagykorúak és a férjezett nők - ők a szülők, a családtanács és a férj irányítása alatt álltak. Azok a személyek, akik a mentális képességükben korlátozottak voltak, de a bíróság határozattal nem rendelkezett róluk, továbbá a tékozlók, nem voltak cselekvőképtelenek (kivéve, ha a bírói tanács úgy ítélte meg). Ők a vagyonuk védelme érdekében a fontosabb ügyleteket önállóan nem köthették meg, a bírói tanács (conseil judiciaire) ügyelt ezekre a szerződésekre, a kisebb értékü dolgokról azonban maguk rendelkezhettek. ${ }^{31}$

Az osztrák jog teljesen cselekvőképtelennek nyilvánította, és a curator oltalma alá helyezte azokat a személyeket, akiknek a belátási képessége mentális betegség miatt hiányzott, és teljesen cselekvőképtelenek voltak a gyermekkorúak is. Részlegesen cselekvőképtelennek minősültek a kiskorúság és a Mündigkeit közötti korba tartozók (Unmündiger), valamint az ezt az életkort már meghaladott, de a nagykorúság határát még el nem ért személyek (Mündiger), akik bizonyos körben már maguk rendelkezhettek (az utóbbi két kategória együttes elnevezése az osztrák terminológiában Minderjähriger, azaz kiskorú). A régebbi osztrák jog a tékozlók gondnokságát (cura prodigi) ismerte, ${ }^{32}$ majd később az ilyen személyeket a kiskorúakkal helyezte hasonló kategóriába, azzal, hogy ők csak a vagyonuk feléről végrendelkezhettek. ${ }^{33}$

A tékozlók a XIX. század második felében a magyar jog szerint is gondnokot kaptak vagyonuk oltalmára. ${ }^{34}$ Az 1877 -es gyámtörvény szerint az önfenntartásra utalt, 14. életévét betöltött kiskorú a saját szerzeménye tekintetében cselekvőképes volt. ${ }^{35}$ A polgári törvénykönyv tervezetek szerint a 12 év alattiak, az akaratelhatározásra képtelen állapotban lévő személyek, és a mentális betegség (vagy tékozlás) miatt gondokság alá helyezettek voltak cselekvőképtelenek. A 12. életévüket betöltött kiskorúak korlátozottan cselekvőképesek voltak, és a gondnokság alá helyezett

${ }^{31}$ Marcel Planiol - Georges RIPERT: Traité pratique de droit civil français Tome I. (Paris: Libraire général de droit \& de jurisprudence 1925) 526. és 762., Colin-CaPitant (19. lj.) 524.

32 Josef Krainz: System des österreichischen allgemeinen Privatrechts Erster Band (Wien: Manzsche Verlags- und Universitäts-Buchhandlung 1894) 471.

33 Josef Unger: System des österreichischen allgemeinen Privatrechts Erster Band (Leipzig: Breitkopf und Härtel 1868) 283., Zweiter Band 26-31., KraInZ (32. lj.) 52-153.

34 Suhayda (29. lj.) 412.

35 Szeiberling (30. lj.) 2., 1877. XX. törvénycikk 3. §. 
nagykorúak is lehettek korlátozottan cselekvőképesek. ${ }^{36}$ (A tékozlók gondnokság alá helyezéséről csak az 1900-as első tervezet rendelkezett, az 1928-as Magánjogi Törvényjavaslat már nem tartalmazta.)

\subsubsection{A KISKORÚAK}

A kiskorúság fokozatait és határát a jogrendszerek ebben az időszakban is a törvénykönyvekben rögzített korhatárok eléréséhez kötötték. A francia Code Civil a nagykorúság elérését a 21. életév betöltéséhez kötötte, a kiskorúságon belül megkülönböztetve a mineur non-émancipé és a mineur émancipé kategóriáit. Utóbbi nem életkorhoz, hanem egy ünnepélyes aktushoz volt kötve, amellyel a kiskorú felszabadult az apai hatalom alól, és bizonyos körben rendelkezési jogot kapott (de nem minősült felnőttkorúnak, ez egy köztes állapot volt a cselekvőképtelenség és a teljes cselekvőképesség között). ${ }^{37} \mathrm{Az}$ osztrák jogban a nagykorúság korhatára a 24. életév volt, a kiskorúság időszaka alatt pedig megkülönböztette a gyermekkort (7 év alattiak), a fentebb már jelzett Unmündigkeit időszakát (8 és 14 év között), és a Mündigkeit korát (14 és 24 év között). Az osztrák jog is ismert egyfajta köztes állapotot, abban az értelemben, hogy a 18. életévét betöltött kiskorú már megtehetett bizonyos magánjogi ügyleteket (házasságra léphetett, végrendelkezhetett). ${ }^{38}$ A magyar ptk. első tervezete, az ekkor már századok óta fennálló gyakorlatnak megfelelően - az 1877-es gyámtörvény szabályaival összhangban - szintén a 24. életév betöltését jelölte meg a nagykorúság határának (és ezt tartalmazta a Magánjogi Törvényjavaslat is). ${ }^{39} \mathrm{Az}$ indoklás szerint - a más európai államok alacsonyabb korhatárt előíró rendelkezései ellenére - a tervezetben azért nem történt meg a nagykorúság korhatárának leszállítása, mert a megélhetés feltételei nehezek voltak, és az egyes életpályákra történő felkészülés időtartamai meghosszabbodtak. ${ }^{40}$ Ezzel együtt a tervezet fenntartotta a kiskorúság (további három évvel történő) meghoszszabbításának lehetőségét is. ${ }^{41}$

A kiskorúak „nagykorúsítása” vonatkozásában, a francia jogban meglévő émancipation lehetősége - amint fentebb már utaltunk rá - nem jelentett tényleges nagy-

${ }^{36}$ Az első magyar Ptk.-tervezet szóhasználata szerint „önjogú” a teljeskorú személy, kivéve, ha (mentális betegség vagy tékozlás miatt) gyámság alatt áll. A Magánjogi Törvényjavaslat szerint - a cselekvőképtelenség állapotát kivéve - korlátlanul cselekvőképes az önjogúak, a nem önjogúak, a kiskorúak és a gondnokság alá helyezett nagykorúak pedig korlátozottan cselekvőképesek (kivéve, ha cselekvőképtelenek). Cselekvőképtelen volt a 12 év alatti személy, aki akar akaratelhatározásra képtelen állapotban van, és akit mentális betegség miatt gondnokság alá helyeztek.

${ }^{37}$ M. Laurens: Principes et Jurisprudence du Code Civil, Tome premier (Paris 1857) 342., PlanioRIPERT (31. lj.) 651-652., Colin-CAPITANT (17. lj.) 639.

${ }^{38}$ UnGer (33. lj.) 281-283, Krainz (32. lj.) 152-153.

${ }^{39}$ Indokolás a magyar általános polgári törvénykönyv tervezetéhez, első kötet (Budapest: Grill 1901) 19.

${ }^{40}$ Indokolás (39. lj.) 19. A kiskorúság meghosszabbítását az 1877-es gyámtörvény is lehetövé tette, ld. 1877: XX. törvénycikk 8-9. §.

${ }^{41}$ A magyar általános polgári törvénykönyv tervezete - első szöveg (Készítették az Igazságügyministerium kebelében szervezett állandó bizottság szerkesztő tagjai) (Budapest: Grill 1900) 2. §. 
korúvá válást, de meghatározott körben lehetővé tette magánjogi ügyletek megkötését. A francia jog ehhez hasonlóan a házasságkötéshez sem a nagykorúsítást, hanem az önálló ügyletek körének kiterjesztését kötötte. ${ }^{42}$ Tekintettel arra, hogy az émancipation lehetősége szülői hozzájárulástól függött, a Code Civil tervezeteinek megvitatása során Cambacérès azt javasolta, hogy a végrendelkezési lehetőséget nem ehhez az aktushoz, hanem korhatárhoz kellene kötni, mert ellenkező esetben a családnak nem áll érdekében az émancipation. ${ }^{43} \mathrm{Az}$ osztrák jog is ismerte a nagykorúvá nyilvánítás lehetőségét, és az ABGB szerint a kiskorú a házasságkötéssel nem vált automatikusan nagykorúvá, hanem lehetősége volt kérelmezni a nagykorúsítást. ${ }^{44}$ Az első magyar ptk.-tervezet szerint a kiskorú nő házasságkötéssel nagykorúvá vált. A tervezet megalkotásakor felmerült mindkét házasfél nagykorúsítása, ${ }^{45}$ ezt később az 1928-as Mtj. foglalta bele a tervezet szövegébe. A 18. életévét betöltött kiskorút, ha ez érdekében állt, és az akaratával egyezett, a szülő meghallgatását követően nagykorúvá lehetett nyilvánítani. ${ }^{46}$

A kiskorúakra vonatkozó jogszabályok megértéséhez, a szülői hatalomra és a gyámságra vonatkozó rendelkezések áttekintése előtt érdekes megnézni a korszak demográfiai változásait és a XX. század elején jelentkező társadalmi-gazdasági folyamatokat. ${ }^{47}$ A magyar Központi Statisztikai Hivatal adatai szerint ${ }^{48}$ Magyarország népessége a XX. századfordulón mintegy 1800000 fővel több volt, mint tíz évvel korábban, az 1890-es népszámláláskor, a népesség gyarapodása 10,3\%-os volt. A népsűrüség is növekedett, egy $\mathrm{km}^{2}$ területre 59,4 lakos jutott a korábbi 53,8 lakossal szemben. A lakosság területi megoszlását nézve a városok felszívó ereje éreztette hatását (ami feltehetően a XIX. század közepétől létesített gyáraknak, az Osztrák-Magyar Monarchia területére is begyűrűző ipari forradalomnak volt köszönhető). Budapest és más ipari városok népessége mindenhol a népszaporodás mértékén túl is növekedett, az alföldi agrárvárosok népessége ezzel szemben nem nőtt. Életkor tekintetében a 15-59 közöttiek számaránya emelkedett, valamint a 60 év felettiek száma is (ami az egészségügy fejlődését jelzi). A 6-11 éves korúak száma kisebb mértékben csökkent, mint korábban, a 12-14 év közöttiek száma pedig már némi emelkedést mutatott. A 6 éven aluliak száma szintén csökkent, ami a születési arányszám csökkenésével is magyarázható volt.

A produktív korosztály számának emelkedésébe a munkát vállaló kiskorúak is beletartoztak. A gyermekmunkát szükségessé tehette mind a népesség növekedése, mind az ipari munkalehetőség általánossá válása (ami a bérek feltehető csökkenése miatt már nem tudta eltartani a megnövekedett népességet). A század eleji magyar

${ }^{42}$ Indokolás (39. lj.) 28.

${ }^{43}$ Discussion du Projet (16. lj.) 19.

${ }^{44}$ Indokolás (39. lj.) 26.

${ }^{45}$ Indokolás (39. lj.) 26-30.

${ }^{46}$ Magyarország Magánjogi Törvénykönyve, Törvényjavaslat 17. §.

${ }^{47}$ Ebben a tekintetben a magyar adatokra szorítkozom, és a franciaországi helyzet tekintetében szépirodalmi utalást teszek Victor Hugo Nyomorultak című regényének (1815-ben kezdődö) cselekményére.

${ }^{48}$ Magyar Statisztikai Közlemények I. kötet: A Magyar Korona országainak 1900. évi népszámlálása, http://konyvtar.ksh.hw/inc/kb_statisztika/Manda/MSK/MSK_001.pdf. 
jog a kiskorú közjogi jogviszonyai körében előfeltételként írta elő a szülő vagy a gyám hozzájárulását a tanoncszerződéseknél (a gyámhatóság azonban pótolhatta a hozzájáruló nyilatkozatot), az önálló iparűzéshez, a házi vagy gazdasági cselédkönyv váltásához, a prostitúció hatósági engedélyezéséhez (itt csak meghallgatásra volt szükség). A szülői vagy gyámi hozzájárulásra nem volt szükség a munkakönyv vagy munkásigazolvány kiállításához, a munkaszerződések megkötéséhez. Ezen túlmenően pedig, az ún. „önfenntartásra utalt kiskorúak” (akik az elsődleges életszükségleteikért saját maguk feleltek) esetében, az erre vonatkozó jogok gyakorlása a közigazgatási jogban egyáltalán nem állt családjogi ellenőrzés alatt. Az ilyen, üzlettel foglalkozó kiskorúak az üzleti tartozásokért saját maguk feleltek. ${ }^{49}$ Az 1877-es gyámtörvény szerint a 18. életévüket betöltött kiskorúak az apa vagy a gyám gyámhatóság által jóváhagyott beleegyezésével önálló ipart űzhettek, és ezzel nagykorúvá váltak. ${ }^{50} \mathrm{Az}$ osztrák jogirodalomban is van utalás arra, hogy a gyámság alatt álló kiskorúak esetében a kereskedelmi üzemi tevékenység felvétele, az apát követő folytatása vagy ilyen üzem bezárása a gyámság feladatát ellátó bíróság jóváhagyását követelte meg. ${ }^{51}$

Különösen nehéz helyzetben voltak a házasságon kívül született gyermekek. A házasságon kívül született gyermek a XIX. század idején a rokonsági kapcsolatokból ki volt zárva az osztrák jogban. A neveléshez, gondozáshoz, ellátáshoz való jog mindkét szülővel szemben megillette, de nem a „családi állás” szerint, mint a házasságból született gyermekek esetén, hanem csak a vagyon mértékéig. Ha az apa nem tudta a gondozást biztosítani, ez a feladat az anyára hárult. A gondozási kötelezettség a nagyszülőkre (a XX. század elején meghozott módosító novelláig, amely az anyai nagyszülővel szemben tartási jogot adott) nem hárult, de a szülők örököseire átháramlott (a házasságból született gyermekkel szemben a házasságon kívül született gyermeknek öröklési joga nem volt). ${ }^{52}$

A XX. századelőn a házasságon kívül született gyermek a magyar jog szerint csak az anyával állt rokonságban, az anya rokonaival, az apával és annak rokonaival nem volt családjogi kapcsolata. A Magánjogi Törvényjavaslat a módosuló bírói gyakorlat alapján (amely a házasságon kívül született gyermek öröklési jogát az anya és rokonai után a „törvényes” gyermekkel szemben is elismerte) már azt tartalmazta, hogy az anyával és annak rokonaival ugyanolyan jogviszonyban állt, mint a „törvényes" gyermek.

A Code Civil a „törvénytelen” gyermek öröklési jogát a XIX. század végén (1896ban) ismerte el, ${ }^{53}$ a házasságból és a házasságon kívül született gyermekek megkülönböztetését pedig a XX. század második feléig fenntartotta. Az osztrák jogban ennek a különbségtételnek a nyomai még a XXI. század elején is fellelhetők voltak.

\footnotetext{
49 Szeiberling (30. lj.) 66. és 184-185.

50 1877: XX. törvénycikk 5. §.

51 KrainZ (32. lj.) 457.

52 KrainZ (32. lj.) 435-437.

53 Carbonnier (8. lj.) 74 .
} 


\subsubsection{A NÖK ÉS A CSELEKVŐKÉPTELEN NAGYKORÚAK}

A Code Civil megalkotását megelőző időszakban a nők nem rendelkeztek ugyanolyan cselekvőképességgel, mint a férfiak, ami azonban nem volt teljesen kizáró jellegü, és részben a családi javak megőrzésével, a háztartás egységes vezetésével is magyarázható volt (ha a férfi vált cselekvőképtelenné, a feleség vette át a háztartás vezetését). A forradalom a jogegyenlőség kimondásával ezeket a különbségeket megszüntette. ${ }^{54}$ A reakció idején, a kódex harmadik tervezete azonban már számos - lényegében cselekvőképtelenséget jelentő - kivételt tartalmazott a nők rendelkezési joga tekintetében: nem vállalhattak kötelezettséget harmadik személyek irányában, a férjük által az egyes ügyletekhez adott felhatalmazás hiányában. ${ }^{55} \mathrm{~A}$ férjezett nők a Code Civil 1804-ben hatályos rendelkezései szerint ${ }^{56}$ - végrendelet kivételével - férjük hozzájárulása nélkül nem köthettek ügyletet, ajándékozás vagy jelzálogszerződés esetén a beleegyezést írásban kellett megtenni.

A nők cselekvőképessége különösen a földtulajdonszerzés vonatkozásában, az öröklési képessége a királyi adományok tekintetében a régebbi osztrák jogban és Magyarországon is korlátozott volt. Az osztrák jogirodalom az ABGB hatálybalépését követő időszakra vonatkozóan már azt közvetíti, hogy a nők a magánjogi viszonyokban a férfiakkal egyenlő helyzetben voltak. ${ }^{57} \mathrm{~A}$ patriarchális családmodell mindazonáltal a XX. század közepéig fennmaradt. ${ }^{58}$

A francia jogban a mentális fogyatékosság megállapítása esetén a bíróság gondnokság alá helyezte a nagykorút. A gondnokság alá helyezésre vonatkozó ítéleteket közzétették, a bírósági hirdetőtáblán és a közjegyzői nyilvántartásban is (utóbbiban azért, mert a fontosabb ügyleteket itt kötötték). 1893-ban egy külön törvény arról is rendelkezett, hogy a gondnokság alá helyezést a cselekvőképtelen személy születési helye szerinti bíróság nyilvántartásba vette, ami bárki számára hozzáférhető volt, másolatot lehetett kérni. ${ }^{59}$

A francia jog ismerte az enyhébb fokú, korlátozott cselekvőképességet jelentő állapotot, amikor az érintett személyt nem helyezte a bíróság gondnokság alá, de védelmet kapott a vagyonát érintő ügyletek megkötése során. ${ }^{60}$

Az osztrák ABGB szerint is cselekvőképtelenek voltak a mentális betegség miatt gondnokság alá helyezett személyek ${ }^{61}$, akik a gondnokság alá helyezést követően nem köthettek ügyleteket, kivételt jelentett a szóbeli ügyletkötés és a végrendelkezés. ${ }^{62}$

Hasonlóan, a magyar ptk.-tervezetek is rendelkeztek a mentális fogyatékossággal rendelkező nagykorú személyek „gyámság” alá helyezéséről (a Magánjogi

${ }^{54}$ Sagnac (7. lj.) 246., Olivier-Martin (6. lj.) 275.

${ }^{55}$ SaGnac (7. lj.) 369-371., Olivier-Martin (6. lj.) 653-654.

${ }^{56}$ Lásd: https://fr.m.wikisource.org/wiki/Code_civil_des_Fran\%C3\%A7ais_1804/Texte_entier.

${ }^{57}$ UNGER (33. lj.) 280.

${ }^{58}$ Franz ByDLINSKI: Einführung in das österreichische Privatrecht (Eisenstadt: Prugg 1975) 97-98.

${ }^{59}$ Planiol-Ripert (31. lj.) 715-716.

${ }^{60}$ Colin-Capitant (17. lj.) 665. és 694., Planiol-Ripert (31. lj.) 762.

${ }^{61}$ UNGER (33. lj.) 288-290.

${ }^{62}$ Krainz (32. lj.) 154-155. 
Törvényjavaslat már a gondnokság kifejezést alkalmazta) ${ }^{63}$ A gyámság/gondnokság alá helyezés a bíróság hatáskörébe tartozott.

\subsection{SZÜLÖI HATALOM, GYÁMSÁG ÉS GONDNOKSÁG}

\subsubsection{KISKORÚAK}

A jog által cselekvőképtelenné nyilvánított személyek helyett mások tehettek jognyilatkozatot. A jogirodalom ennek indokát a cselekvőképtelenek saját védelmében látta, és részben a társadalom, a harmadik személyek érdekének is tekintette. ${ }^{64} \mathrm{~A}$ gyermekek esetén a védelem, gondoskodás, a vagyon kezelésének joga és kötelezettsége a kapcsolat természetéből adódóan a szülőket (kezdetben csak az apát) illette.

A XIX. századi család szerkezetnek megfelelően a gyermek az apai hatalom (puissance paternelle) alatt állt. Az apa halála után a gyermek gyámság alá került. A francia jogban az apai hatalom és a gyámság jogintézménye egymás mellett is fennállhatott: az apa halála után az apai hatalom az anyát illette, de sokszor ez csak a gyermek személyére vonatkozóan jelentett felügyeletet, a gyermek vagyonának igazgatása (administration légale) elvált a személyi kérdésektől, és ez a gyámot illette. ${ }^{65}$ A gyám a gyermek személyét érintő kérdésekben csak mindkét szülő halálát követően dönthetett. A francia jog jellegzetessége volt az is, hogy a gyámot illető jogok és kötelezettségek gyakorlása a családi kötelékeken belül maradt. A gyámi hatalom (puissance tutélaire) elsődlegesen a gyermek rokonaiból álló családtanácsot (conseil de famille) illette, a békebíró (juge de paix) elnökletével. A családtanács összetétele nem volt állandó, időről időre változhatott. A napi ügyekben pedig a gyám (tuteur) járt el, gondoskodott a kiskorúról, és ellátta a képviseletét, a fontosabb kérdésekben a családtanács jóváhagyása mellett. A helyettes gyám (subrogétuteur) amellett, hogy szükség esetén ellátta a gyám helyettesítését, állandó jelleggel ellenőrizte is a gyámot. A családtanács döntései ugyanakkor bírói kontroll (tribunal) alatt álltak, és a különösen fontos ügyletek megkötéséhez is szükséges volt a bíróság közreműködése. A házasságon kívül született gyermekek esetében a családtanács feladatait egészében a tribunal látta el (ők minden esetben gyámság alatt álltak). ${ }^{66}$

A mineur émancipé a saját személyi kérdéseiben már döntési jogosultsággal és vagyona felett korlátozott rendelkezési joggal bírt. Öt az ügyeiben a curateur segítette, aki azonban nem a képviseletét látta el, hanem jelen volt az ügyletek megkötése során. ${ }^{67}$

A gyermek az osztrák jogban szülői hatalom alatt állt azzal, hogy a szülői egyetértés hiányában az apa akarata volt irányadó. Az apai hatalmának körébe tartozott a gyermeknek adandó nevelés módjának megválasztása, a házasságkötéshez történő

\footnotetext{
${ }^{63}$ A magyar általános polgári törvénykönyv tervezete - első szöveg (41. lj.) 7. §, Mtj. (46. lj.) 12. §

${ }^{64}$ Planiol-Ripert (31. lj.) 302.

${ }^{65}$ Colin-Capitant (17. lj.) 567., Planiol-Ripert (31. lj.) 420. és 426.

${ }^{66}$ Planiol-Ripert (31. lj.) 315., 467., 486. és 556., Colin-Capitant (17. lj.) 567.

${ }^{67}$ Planiol-Ripert (31. lj.) 659.
} 
hozzájárulás (az apa beleegyezése nélkül kötött házasságot meg lehetett támadni). Az apa joga volt a gyermek vagyonának kezelése is (ebbe nem tartozott bele az, amit a gyermek maga szerzett), és e vagyon felett szabadon rendelkezhetett, kötelezettséget vállalhatott. A gyermek számára gyámot csak az apa nevezhetett, a gyámság időben követte az apai hatalom körébe eső feladatok ellátását, vagyis az apai hatalom és a gyámság egymás mellett soha nem álltak fenn. ${ }^{68}$ A XIX. században a gyám feladatait Ausztriában is elsődlegesen a hozzátartozók látták el, nekik kellett jelezniük a bíróságnak azt, hogy gyámot kell kinevezni a gyermek részére. A gyámság, a kiskorú képviselete azonban az osztrák jog szerint a funkciót tekintve a bíróságot illette, és a kinevezett gyám (Vormund) lényegében a bírói szerepkör megtestesítője volt. A fontosabb ügyletek megkötése során azonban a bíróság járt el, ezt a feladatot nem adhatta át a gyámnak. A gyámi feladatok elfogadása állampolgári kötelezettség volt, és az arra való alkalmasságot vizsgálni kellett (kivéve az anya, a nagyapa és a nagyanya kinevezése esetében, mert róluk feltételezték, hogy lelkiismeretesen ellátják a tisztséget). A kiskorú az anya felügyelete alatt maradt azzal, hogy a nevelés a gyám kötelezettsége volt, amit a kiskorú bevételeiböl, vagyonából lehetett fedezni. A vagyon megőrzése tekintetében a bíróság felügyeletet gyakorolt. A kiskorúval szemben a gyámi feladatok ellátása kapcsán mind a gyám tisztségét ellátó személy, mind a bíróság (a vétkesen eljáró bírósági ügyintéző) felelősséggel tartozott. ${ }^{69}$

Az Országbírói Értekezlet által megállapított szabályok alapján a gyermek a magyar jogban is az apai hatalom alatt állt. Az apai hatalom és a gyámság a magyar jogban sem állhatott fenn egyidejủleg. Az anyát a férje halála után csak a gyámság joga illette, és nem az első helyen, hanem a nagyapát követően (a sorrendiségen az Mtj. változtatott, előre helyezve az anyát). ${ }^{70} \mathrm{~A}$ magyar jog a törvényes és a rendelt gyámság intézményét ismerte: a törvényes és természetes gyámság joga az életben maradt szülöt, a csupán törvényes gyámság a legközelebbi rokonokat illette. Ha sem végrendeletben kijelölt, sem törvényes gyám nem volt, a kiskorú rendelt gyámot kapott. ${ }^{71}$ A gyámi tisztség ellátásának feladata tehát megillette az anyát, aki a gyermek vagyonának kezeléséről lemondhatott, és ebben az esetben az anya mellé gondnokot is kirendeltek, abból a célból, hogy az anyának segítségére legyen a gyermek ügyeinek intézésében. Az 1877-es gyámtörvény szerint az apának jogában állt végrendeleti úton gyermekei részére családi tanácsot jelölni, nagyobb összegű hagyaték esetén. A gyámi feladatkört ellátó francia családtanács intézményével szemben ezt a típusú családi tanácsot az apa állította fel, mintegy korlátként vagy biztosítékként az anyával és a gyám feladataival, valamint a gyámhatóság hatáskörével szemben. A családi tanács felállítását az anya is kérhette (a belügyminisztertől), az anya mint természetes és törvényes gyám feladatai ebben az esetben is megmaradtak, a családi tanács létéből fakadó korlátozásokkal. ${ }^{72} \mathrm{~A}$ francia család-

${ }^{68}$ Krainz (32. lj.) 430-433.

${ }^{69}$ KrainZ (32. lj.) 447-454.

70 Suhayda (29. lj.) 410-411., Szeiberling (30. lj.) 215.

71 Suhayda (29. lj.) 414.

72 Szeiberling (30. lj.) 205. és 334., 1877: XX. törvénycikk 151-168. §. 
tanáccsal szemben továbbá a gyámi tisztet ellátó hozzátartozók nem automatikusan léptek be ebbe a tisztségbe, hanem az alkalmasságuk vizsgálatát követően hatósági megerősítésre volt szükség. Az ellenőrző gyám intézményére - a francia megoldással szemben - csak kivételesen, akkor volt szükség, ha a gyám kezelésébe tartozó vagyon nagysága miatt ezt a kiskorú érdeke megkívánta ${ }^{73}$ (de maga a gyámi feladat is a közigazgatási szervezet keretében szerveződött).

A korszak családról alkotott képét tükrözi, hogy a vizsgált jogrendszerek közül egyedül az osztrák jogban volt szülői hatalom, de ez a jogintézmény is csak elnevezésében felelt meg annak, tartalmában az apai hatalomhoz hasonló volt, mert az apát több jogosítvány illette. Az apa halálát követően az apai hatalom a francia és az osztrák jogban is megillette az anyát, a magyar jogrendszerben az anya gyámi szerepet kapott. Árnyalja a képet, hogy az anya személyi felügyelete mellett a vagyoni kérdésekre Franciaországban is nevezhető volt gyám, és az osztrák jogban is jellemző volt, hogy az apa gyámot nevezett, aki nemcsak a vagyoni kérdésekben döntött, hanem a kiskorú nevelésének feladatát is ellátta. A gyámi feladatok családban maradása a francia jogban volt leginkább jellemző. Itt a családtanács majdhogynem önállóan járt el, és csak a fontosabb ügyekben kapott bírósági felügyeletet. A gyámi tisztség hozzátartozók általi ellátása, a rokonok szerepe Ausztriában és Magyarországon is fontos volt (a gyám személye az osztrák jogban is elsősorban a hozzátartozók köréből került ki, a magyar jogban a kiskorú természetes gyámja az anya volt, más hozzátartozókat is törvényes gyámság illette, és az apa családi tanácsot nevezhetett). Fontos különbség a francia és az osztrák, illetve magyar modell között, hogy míg Franciaországban a bíróság csupán ellenőrző funkciót látott el a családi tanács felett, addig a gyámsági funkciót Ausztriában lényegében a bíróság látta el, és nevezte ki az egyes feladatokra az erre alkalmasnak ítélt személyt. Magyarországon mindez hasonlóan, csak a közigazgatás keretei között történt: az 1877-es gyámtörvény szerint a gyámság alatt álló kiskorúak személyi és vagyoni ügyeinek intézése a gyámhatóság feladata volt, és a gyám csak mint „a gyámhatóság közege” járt el. Az 1928as Mtj. ezzel szemben már úgy rendelkezett, hogy a gyám a törvénynél fogva látja el ezt a feladatát (és a gyámhatóság csak felügyeletet gyakorol). ${ }^{74}$

A házasságból született gyermekek számára nem mindig volt lehetséges a szülők halálát követően hozzátartozót jelölni ki gyámként. A XIX. század második felétől erősödött Ausztriában és Magyarországon, elsősorban a házasságon kívül született gyermekek felügyeletének megoldása érdekében a hivatásos gyámi rendszer. A hivatásos gyámi rendszer kialakításának okait a jogirodalom egyrészt a csecsemőhalálozás elleni küzdelemben, másrészt az új ipari és gyári üzemek létesítésében, a termelés fokozódásában és a családi kapcsolatok lazulásában látta. ${ }^{75}$

73 Suhayda (29. lj.) 591.

74 Suhayda (29. lj.) 508.

75 Schopf (30. lj.) 30-46. és 87. 


\subsubsection{A CSELEKVŐKÉPTELEN NAGYKORÚAK}

A cselekvőképtelen nagykorúak tekintetében a Code Civil kezdettől fogva két kategóriát ismert, a bíróság által cselekvőképtelennek nyilvánított személyeket (interdiction judiciaire) és az enyhébb fokú mentális fogyatékosságban érintetteket (faibles d'esprit), akik a conseil judiciaire segítségére (assistance) szorultak. ${ }^{76}$ A régi francia jog szerint minden, bíróság által cselekvőképtelennek nyilvánított személyt automatikusan gondnokság alá kellett helyezni. A Code Civil annyiban változtatott ezen a gyakorlaton, hogy ismerte a gondnokság alá helyezés nélkül fennálló cselekvőképtelen állapotot is ${ }^{77}$ amely az egyes ügyletek megkötése tekintetében bizonyítási kérdés volt. ${ }^{78}$ A gondnokság alá helyezési kérelmek száma a XIX. század közepén évi 500 és 800 közét volt tehető, és ez a szám nem emelkedett, a kérelmek száma 1888ban 772, 1909-ben 613 volt (a gondnokság alá helyezést az esetek túlnyomó többségében a család kérte).$^{79}$ A gondnokság alá helyezésről rendelkező ítéletek megelőzték az intézményi elhelyezéseket, amelyeknek a száma a század közepétől kezdve fokozatos emelkedést mutatott (az intézményi elhelyezésekről nem a Code Civil, hanem 1838-ban külön törvény rendelkezett). ${ }^{80}$ 1871-ben 40589 személyt, 1900ban 87428 személyt (1936-ban már 138326 személyt) helyeztek el intézményben. Összehasonlításként, Magyarországon is a XIX. század második felében épült meg az első két intézményi elhelyezést biztosító épület, 1863-ban a 250 fő ellátására alkalmas nagyszebeni, 1868-ban az összesen 500 személy befogadására alkalmas lipótmezei intézmény nyílt meg. Emellett több olyan kórház volt, ahol tudtak betegeket fogadni, és magánintézmény is müködött. Magyarországon ebben az időszakban kórházban és bentlakásos intézményben összesen 1200 személyt lehetett elhelyezni. ${ }^{81}$

A nagykorúak cselekvőképtelensége tekintetében az osztrák ABGB jellegzetessége az volt, hogy a megszületésének teljes évszázadában nem különböztetett a mentális betegség fokozatai szerint, hanem csak egyféle kategóriát ismert, a teljes cselekvőképtelenséget. ${ }^{82}$

A magyar polgári törvénykönyv tervezete a francia Code Civil terminológiáját követte annyiban, hogy a nagyobb fokú gondnokság kategóriát gyámságnak nevezték, és az enyhébb fokú gondnokságnak tartotta fenn a gondnokság kifejezést. A gyámság alatt álló személyek cselekvőképtelenek voltak, a gondnokság alatt

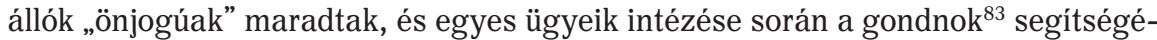

76 Alex WeIll - François Terré: Droit Civil, Les personnes, La famille, Les incapacité (Paris: Dalloz 1983) 877.

77 Ennek a kategóriának a bevezetését az indokolta, hogy a család sok esetben nem kérte a bíróságtól a mentális állapot miatt a gondnokság alá helyezést. Ld. WeILL-TERRÉ (76. lj.) 877.

${ }^{78}$ Colin-Capitant (17. lj.) 673-675.

79 Colin-Capitant (17. lj.) 677.

${ }^{80}$ Planiol-Ripert (31. lj.) 686-687. és 736., Colin-Capitant (17. lj.) 668.

${ }^{81}$ KozÁRI Mónika: „Tébolydák Magyarországon a kiegyezés után” Kaleidoscope - Müvelődés-, Tudomány- és Orvostörténeti Folyóirat 2014/9., https://doi.org/10.17107/KH.2014.9.64-73.

82 UNGER (33. lj.) 289.

${ }^{83}$ Gondnokot akkor is kijelöltek, ha a gyámság alá helyezett nagykorú személy esetében a gyám valamilyen ok miatt nem tudott eljárni - (vagyis eseti jelleggel). Lásd 1914-es tervezet 326-328. §§. 
vel jártak el. ${ }^{84} \mathrm{Az}$ 1914-es tervezet szerint a gyámi tisztre a házastárs, az apa, az anya, az elismert törvénytelen gyermek apja, az apai nagyapa és az anyai nagyapa voltak jogosultak, ebben a sorrendben.

\section{A CSELEKVŐKÉPTELENEKRE VONATKOZÓ SZABÁLYOZÁS VÁLTOZÁSAI A XX. SZÁZADBAN}

\subsection{KISKORÚAK}

A Code Civil nagyobb arányú módosításai a XX. század elején kezdődtek. A nagy ipari üzemek létrejötte, a munkástömegek kialakulása, az első világháború és az azt követő gazdasági válság időszakában a gazdasági liberalizmust felváltotta az állami beavatkozások kora, ami a gazdasági területek szabályozása (tulajdonjog, szerződések) mellett a családra vonatkozó joganyagra is hatással volt. ${ }^{85}$ A személyekre vonatkozó szabályok lényegi módosításai a XX. század második felében történtek: 1965-ben váltak a férfiak és nők egyenjogúvá, a szülői hatalom jogintézményét (apa és anya egyformán) 1970-ben vezették be, ${ }^{86}$ a törvénytelen és törvényes gyermek egyenlővé tétele a gyámság tekintetében 1964-ben, a származás vonatkozásában 1972-ben történt meg. A hagyományos családmodell megváltozásának ellensúlyaként, a család egységének fenntartása és a születések számának ösztönzése érdekében, népességpolitikai okokból is, a XX. század közepétől bevezették Franciaországban a családok számára nyújtott szociális ellátási formákat (1939ben megalkotott Code de la famille). ${ }^{87}$

Az osztrák ABGB-t a XX. század elején három novella ${ }^{88}$ módosította. Az új rendelkezések szerint a házasságon kívül született gyermek beletartozott az anya családjába, az anyai nagyanyával szemben tartáshoz való jog illette. ${ }^{89} \mathrm{~A}$ novella törvénybe foglalta azt a már meglévő gyakorlatot, hogy az apa által elismert gyermek számára a bíróság az apa vagyonához mérten, mérlegelés alapján tartási hozzájárulást állapíthatott meg. ${ }^{90} \mathrm{~A}$ nők és a férfiak egyenlősége vonatkozásában előrelépést jelentett, hogy a nők is vállalhattak (férjük beleegyezésével) gyámságot (nem csak a saját gyermekük tekintetében - a saját gyermek esetén a férj hozzájárulására nem

\footnotetext{
${ }^{84}$ Indokolás (39. lj.) 37.

85 CARbonnier (8. lj.) 74.

${ }^{86}$ A Code Civil eredeti 373. szakasza szerint a házasság fennállása alatt egyedül az apa gyakorolja a szülői hatalmat. Az 1970-ben hozott törvény által bevezetett új szöveg, az 1971. január 1-jétől hatályos (azóta kisebb szövegváltoztatások miatt többször módosított) 372. szakasz szerint az apa és az anya együtt gyakorolják a szülői hatalmat.https://www.legifrance.gouv.fr/codes/id LEGIARTI000006426488/1971-01-01/.

87 CARbonnier (8. lj.) 74.

88 1914. október 12-i, 1915. július 22-i és 1916. március 19-i császári rendeletek.

${ }^{89}$ Rudolf Ehmer: Die drei Novellen zum Allg. Bürgerl. Gesetzbuch und die Entmündigungsordnung (Graz: Mosers 1917) 7.

${ }^{90}$ Ehmer (89. lj.) 11.
} 
volt szükség). Különösen indokolt volt ez kisgyermekek, lányok esetében, ha nem volt anya vagy nagymama a családban. ${ }^{91} \mathrm{Az}$ apához hasonlóan az anya is nevezhetett gyámot a gyermeke számára (vagy meghatározott személyt kizárhatott a gyámságból), és az apa halálát követően az anya mint törvényes gyám már megelőzte az apai nagyapát. ${ }^{92}$ A XIX. század második felében hozott rendelkezések alapján már meglévő gyakorlat volt, hogy ha a kiskorút intézeti nevelésbe vették, és nem volt ingatlan- vagy jelentősebb vagyona, akkor nem kellett számára gyámot nevezni, a gyámi tisztséget az intézet vezetője gyakorolta. Az árvaház gyámi tisztet betöltő vezetője ily módon apasági és tartási pereket indíthatott a természetes apa ellen. ${ }^{93} \mathrm{Az}$ intézeti gyámságra vonatkozó szabályt belefoglalták a kódexbe azzal, hogy a bíró - ha a kiskorú érdekében szükségesnek látta - rendelkezhetett gyám kinevezéséről, de csak a vagyon igazgatását érintően, és nem a nevelésre vonatkozóan. ${ }^{94} \mathrm{~A}$ törvénykönyv módosítása rendelkezett a más hivatásos gyámok kirendelésének lehetőségéről is, ha nem volt a gyámi feladatok ellátására alkalmas személy. Ezek a jogintézmények elsődlegesen a házasságon kívül született gyermekeket érintették. ${ }^{95}$

Az 1877-es gyámtörvény még apai hatalomról beszélt, az 1928-as Magánjogi Törvényjavaslat már a gyermek felett a szülői hatalom fennállását definiálta, de a szülői hatalom gyakorlásának sorrendiségében különbséget tett. ${ }^{96}$ A gyámtörvény szerint a kiskorú vagyonának jövedelmét a tartásra és nevelésre kellett fordítani, a felesleg az apát illette. ${ }^{97}$ A szülők háztartásában élő gyermek keresete felett a jogirodalomban hivatkozott bírói gyakorlat szerint a szülők rendelkeztek, abban az esetben is, ha az a gyermek eltartására fordított költségeket meghaladta. ${ }^{98}$

Az intézeti gyámság Magyarországon is ismert volt. ${ }^{99}$ A magyarországi falvakban az elnéptelenedés veszélye fenyegetett, a nehéz megélhetési viszonyok korlátozóan hatottak a születésekre, az intézkedéssel a házasságon kívül született gyermekek túlélését akarták biztosítani. ${ }^{100}$ A kialakuló hivatásos gyámi rendszert a meglévő gyámhatósági rendszerbe illesztették. A házasságon kívül született gyermekek helyzetét és a hivatásos gyámi rendszer mikénti működését jelzi az a hivatkozás a jogirodalomban, hogy ha a kiskorú nő „türelmi bárcát” kért, és tizennyolc év alatti volt,

91 Ehmer (89. lj.) 13-14.

${ }^{92}$ Ehmer (89. lj.) 15.

${ }^{93}$ Schopf (30. lj.) 30.

94 Sснорғ (30. lj.) 26-27.

95 Schopf (30. lj.) 28.

${ }^{96}$ Mtj. (46. lj.) 268. § A szülői hatalom gyakorlása a kiskorú törvényes gyermek fölött elsősorban az atyát illeti. Mellette az anya a házassági életközösség tartama alatt csak a gyermek gondviselésével járó szülői jogokat gyakorolja. 269. § A kiskorú törvényes gyermek fölött az anya jogosult a szülői hatalom gyakorlására, ha az atyának szülői hatalma megszünt vagy szünetel, vagy ha az atya ténylegesen gátolva van a szülői hatalom gyakorlásában. (...)

97 1877: XX. törvénycikk 16. §.

98 Szeiberling (30. lj) 134-135.

${ }^{99}$ Szeiberling (30. lj) 48. o.

${ }^{100}$ 1911-ben a gyermekvédelmi nyilvántartás szerint 2127 gyermek született házasságon kívül (ebböl 989 gyermek kiskorú anyától). Lásd Schopf (30. lj.) 103. 
értesítették a gyermekvédelmet, és intézkedtek a javító nevelésbe vétel iránt, tizennyolc év feletti nő esetében pedig leánykereskedelem ellen megalakult egyesület figyelmét hívták fel. ${ }^{101}$

A házasságon kívül született gyermekek helyzetét Magyarországon az 1946. évi XXIX. törvénycikk rendezte, megszüntetve a „törvényes” és „törvénytelen” származás közötti különbségtételt. A törvénycikk 19. §-a szerint a házasságon kívül született gyermek mind az anya, mind az apa, és mindkettőjük rokonainak egyaránt rokona, és a rokonság alapján úgy illetik jogok, és úgy terhelik kötelezettségek, mintha házasságból született volna.

A XX. század elejétől kezdve Magyarországon is szociális ellátás illette meg a gyermekes alkalmazottakat, az 1912. évi XXXV. törvény bevezette a családi pótlékot (nőalkalmazottaknak csak akkor járt, ha a gyermek apja meghalt, keresőképtelen vagy különváltan élt), az 1937. évi XIII. törvénycikk pedig rendelkezett a többgyermekes alkalmazottak tekintetében a családi pótlék összegének felemeléséről.

A családi jogviszonyok szabályait Magyarországon 1953-tól kezdődően az 1877es gyámtörvényt felváltva a családjogi törvény tartalmazta, amely egészen a 2013as Ptk. megszületéséig elkülönült a polgári jog anyagától. ${ }^{102} \mathrm{Az}$ 1952-es családjogi törvény rendelkezései szerint a kiskorú szülői felügyelet vagy gyámság alatt állt, a szülői felügyeletet a szülők együttesen gyakorolták. ${ }^{103}$ A gyámság viselése elsősorban a szülő által nevezett gyám feladata volt (a szülő bármely személyt ki is zárhatott a gyámságból), ilyennek hiányában a gyámhatóság jelölte ki a gyámot, erre alkalmas rokont, ilyennek hiányában arra alkalmas más személyt. Az állami gondozás alatt álló kiskorú intézeti gyámság alá tartozott. ${ }^{104}$

\subsection{NAGYKORÚAK}

A Code Civil cselekvőképtelenekre vonatkozó joganyagában jelentős változtatást hozott az 1968-as reform. A gondnokság alá helyezés nélkül is cselekvőképtelenek kategóriája mellett a módosítás bevezette a „jog oltalma” (sauveguarde de justice) jogintézményét, és a gondnokság két formáját (tutelle és curatelle). A minimum-védelmet jelentő - orvosi vélemény alapján - a jog oltalma alá kerülő személy valójában nem cselekvőképtelen, a vagyonára nem ügyel más személy, nincs képviselője vagy állandó segítője, de a polgári jogi ügyletek során a jogszabály védelmet biztosít számára. A bíróság gondnokság (tutelle) alá akkor helyezi a személyt, ha testi vagy mentális fogyatékossága miatt a polgári ügyletei során képviseletre szorul (ez a kategória, az egyéni és rugalmasabb elbírálást jobban lehetővé tevő módon

\footnotetext{
${ }^{101}$ Schopf (30. lj.) 75.

${ }^{102}$ Ld. a házasságról, a családról és a gyámságról szóló, 1953. január 1-jén hatályba lépett 1952. évi IV. törvényt.

${ }^{103}$ Ld. a házasságról, a családról és a gyámságról szóló, 1953. január 1-jén hatályba lépett 1952. évi IV. törvény 70. és 72 . §-át.

${ }^{104}$ Ld. a házasságról, a családról és a gyámságról szóló, 1953. január 1-jén hatályba lépett 1952. évi IV. törvény 94-100. §-ait.
} 
megújítva, megfelel a korábbi interdiction judiciaire nevű intézménynek). A curatelle az előző két jogintézmény között helyezkedik el, a gondnokságnak ezt az enyhébb, csak korlátozott cselekvőképességet eredményező formáját akkor állítja fel a bíróság, ha a személy mentális vagy testi állapota valamilyen elváltozást mutat, és segítőre (assistance) van szüksége. ${ }^{105}$

A nagykorúak cselekvőképtelenségére vonatkozó „köztes” kategória („korlátozott cselekvőképesség”) az osztrák jogban a XX. századelőn hozott módosítással született meg. ${ }^{106}$ A tékozlók részleges cselekvőképtelenségét már ismerte az ABGB, a módosítás azonban - a gyakorlatban szükségesnek mutatkozó esetekre hivatkozva - szélesítette a curator nevezésének eseteit (abban az esetben is sor kerülhetett erre, ha nem hitelügyletek útján, hanem más módon történt felelőtlen költekezés). ${ }^{107}$

Az 1959-es Ptk. hatályba lépéséig az 1952-es magyar családjogi törvény végrehajtási rendelete tartalmazta a cselekvőképességre vonatkozó szabályokat. ${ }^{108}$ Mind a családjogi törvény végrehajtási rendelete, mind később az 1959-es Ptk. a cselekvőképességet kizáró és korlátozó gondokság alá helyezésről egyaránt rendelkezett, továbbá mindkettő ismerte a gondnokság alá helyezés nélkül fennálló cselekvőképtelen állapotot is. ${ }^{109} \mathrm{Az}$ 1959-es Ptk. a szövegezésben változtatott, és ezek a szabályai hosszú évtizedekig, a 2001. évi XV. törvénnyel bekövetkezett módosításig lényegében változatlanul hatályban voltak.

\section{A CSELEKVŐKÉPTELENEKRE VONATKOZÓ SZABÁLYOZÁS LEGÚJABB VÁLTOZÁSAI}

\subsection{A KISKORÚAKRA VONATKOZÓ SZABÁLYOK}

A Code Civil 1974. július 5-i törvénnyel történt módosítása a kiskorúság korhatárát a 18. életévben határozta meg. A Code Civil hatályos 413. cikke szerint a nagykorúsítást bármelyik szülő (vagy a családi tanács) kérheti a 16. életév betöltését követően, és a nagykorúsított fiatal felnőtt (mineur émancipé) bármilyen magánjogi ügyletet megköthet (a házasságkötést és az örökbefogadást csak a kiskorúakra irányadó szabályok szerint teheti meg). A kiskorúak képviseletét a törvényes képviselő (szülő vagy gyám látja el). Ha mindkét szülő meghalt, vagy a szülői felügyeletet nem gyakorolhatják, a kiskorú gyámság alatt áll. A gyám kinevezése mellett a bíróság a családtanácsot is kialakítja, amelynek tagjai a gyám és a helyettes gyám mellett a szülők, hozzátartozók, és más, a gyermek érdekében eljáró, vele érzelmi kapcsolatban álló személyek is lehetnek.

\footnotetext{
${ }^{105}$ A három jogintézmény részletes leírását ld. WeILL-TERRÉ (76. lj.) 894966.

${ }^{106}$ Schopf (74. lj.) 202-203.

${ }^{107}$ Schopf (74. lj.) 205.

${ }^{108}$ 1952. évi 23. törvényerejű rendelet a házasságról, a családról és a gyámságról szóló 1952. évi IV. törvény hatálybalépése és végrehajtása, valamint a személyi jog egyes kérdéseinek szabályozása tárgyában.

${ }^{109}$ Ld. a Polgári Törvénykönyvről szóló 1959. évi IV. törvény 13., 16. és 17. §-ait.
} 
Ausztriában a kiskorúakra vonatkozó szabályozást 2001-ben a KindschaftsÄnderungsgesetz alapjaiban megváltoztatta. A hétéves korhatár alatti „gyermek” definíciót megszüntették, a 14. életévét betöltött Mündiger kategória megmaradt (ők korlátozottan cselekvőképesek), de már csak a 18. életév betöltéséig (a nagykorúság új korhatára) tartott. ${ }^{110}$ A cselekvőképesség és a vétőképesség fogalmai mellett a 2001-es átfogó módosítás egy új fogalmat alkotott, a személyes ügyekben történő cselekvőképesség kategóriáját (Handlungsfähigkeit in persönlichen Angelegenheiten). Ezekben az ügyekben is akaratnyilatkozat tételről van szó, de a saját belátási képességet bizonyos mértékig feltételező, árnyaltabb kategóriát jelent, a cselekvőképesség és a vétőképesség között. Az irodalom példaként a sporttevékenységet említi, ahol a cselekvés tényéből (nem jogügyletből) adódóan fennáll a saját akarat (a belátás esetleges hiányát pedig a törvényes képviselő léte áthidalja). ${ }^{111}$ Hasonlóan, az orvosi kezelésekbe történő beleegyezésre sem az általános cselekvőképességi szabályok vonatkoznak a novella óta: az ilyen kezelésekbe történő hozzájárulások szabályait az osztrák jogban nem az életkorhoz igazítják, hanem attól teszik függővé, hogy a kiskorú a szükséges ítélőképesség birtokában van. A 14. életévüket betöltött kiskorúakra vonatkozóan a jog vélelmezi az ítélöképességet, de ez korábbi életkorban is fennállhat. Ha a 14. életévét betöltött gyermek később érné el a kornak megfelelő érettséget, a bíróságnak ki kell mondania, hogy nem ítélőképes vagy nem cselekvőképes, és ezzel cselekvőképtelenné válik (a nagykorúság eléréséig). ${ }^{112}$

A 2001-es Kindschafts-Änderungsgesetz terminológiai újítást is bevezetett. A korábbi gyám (Vormund) és gondnok (Sachwalter) megjelölés helyett a szülői felügyelet alatt nem álló gyermekekre vonatkozóan bevezette egységesen a másik személyről való gondoskodás (Obsorge einer anderen Person) fogalmát. ${ }^{113} \mathrm{Ha} a$ gondoskodással a szülők vagy a nagyszülők nem bízhatók meg, a bíróság elsősorban hozzátartozót vagy más, a gyermekhez közel álló személyt jelöl ki a feladat ellátására.

A szülő és gyermek viszonyában a házasságból és a házasságon kívül született gyermekek tekintetében a reformok az egyenlősítés irányába mutattak. A házasságon kívül született gyermek ugyanúgy rokoni kapcsolatban volt mindkét szülővel (az apával akkor, ha az apaságot megállapították), de az anyát illette a gondozás joga és kötelezettsége. Az ABGB erre vonatkozó szakaszát az osztrák Alkotmánybíróság a Landesgericht Wien indítványa alapján 2012. június 28-án hozott határozata alkotmányellenesnek nyilvánította, és megsemmisítette. ${ }^{114}$ Az osztrák Alkotmánybíróság megvizsgálta az Emberi Jogok Európai Bíróságának esetjogát, és az ABGB vonatkozó rendelkezését az Emberi Jogi Egyezmény nemek szerinti megkülönböztetést tiltó 14. cikkével, a magánélet védelmét kimondó 8. cikkel összefüggésben, ellen-

\footnotetext{
${ }^{110}$ Koziol-Welser (20. lj.) 53. és 55.

${ }^{111}$ Koziol-Welser (20. lj.) 54 .

${ }^{112}$ Koziol-Welser (20. lj.) 58-59., Helmut Koziol - Peter Bydlinski - Raimund Bollenberger: Kurzkommentar zum ABGB (Wien: Springer 2010) 130.

${ }^{113}$ Koziol-Welser (20. lj.) 561.

${ }^{114}$ Lásd: https://www.vfgh.gv.at/downloads/VfGH_G_114-11_Obsorge.pdf.
} 
tétesnek találta. A 2013-ban történt újabb módosítás óta a gyermek szülei, ha nem élnek házasságban, kérhetik a közös gondozás megállapítását. ${ }^{115}$

Az 1959-es magyar polgári törvénykönyv a nagykorúság korhatárát a 18. életév betöltéséhez kötötte, a 12. életévüket betöltött kiskorúak (ezt a korhatárt az 1959es ptk. 1977-ben történt módosítása a 14. életévre emelte) korlátozottan cselekvőképesek voltak. ${ }^{116} \mathrm{~A} 18$. életévét be nem töltött kiskorú a házasságkötéssel nagykorúvá vált. Ezeket a rendelkezéseket a 2013-ban megszületett polgári törvénykönyv megtartotta. ${ }^{117}$ A korlátozottan cselekvőképes kiskorú a hatályos magyar jogban is önállóan tehet olyan személyes jellegű jognyilatkozatot, amelyre jogszabály feljogosítja. Így az érintett gyermek hozzájárulása kell az örökbefogadásához, és a rá vonatkozó teljes hatályú apai elismerő nyilatkozathoz, a korlátozottan cselekvőképes gyermek közvégrendeletet is tehet. ${ }^{118}$

A 2013-as Ptk. negyedik könyve tartalmazza a családjogi kapcsolatokra vonatkozó szabályokat. A gyermek érdekének védelme tekintetében a 4:2. § (2) és (3) bekezdése úgy rendelkezik, hogy a gyermeknek joga van ahhoz, hogy saját családjában nevelkedjék, és ha nem nevelkedhet saját családjában, akkor is biztosítani kell számára, hogy lehetőleg családi környezetben nőjön fel. E törekvéssel összhangban a gyermekvédelmi törvény 2014-től hatályos módosítása (a rendelkezés 2017-ben újra módosult) úgy rendelkezik, hogy a gyermek átmeneti gondozását és otthont nyújtó ellátását elsősorban befogadó szülőnél kell biztosítani, és 12 év alatti gyermek esetén ettől kizárólag a törvényben meghatározott esetekben lehet eltekinteni (tartós betegség vagy súlyos fogyatékosság miatt nem áll a gyermek érdekében vagy nem lehetséges, testvérek együttes elhelyezése okán, illetve az intézményi elhelyezést a szülő kéri, és az nem ellentétes a gyermek érdekével). A Központi Statisztikai Hivatal adatai szerint ${ }^{119} 2004$ és 2019 között a gyermekotthonokban ellátott gyermekek és fiatal felnőttek száma 10149 összlétszámról 7072-re csökkent (ezen belül a hosszabb időtartamot gondozásban töltött személyek száma csökkent erőteljesebben), a nevelőszülőknél elhelyezett gyermekek és fiatal felnőttek száma 11127 összlétszámról 15 526-ra növekedett (ezen belül csak a 10 évnél kevesebb időt itt töltött személyek száma nőtt, míg a 10-17 év közötti, illetve a 17 évnél több időt nevelőszülőknél töltött személyek száma csökkent). Szintén a KSH adatai szerint ${ }^{120}, 2014$ és 2019 között

${ }^{115}$ Kindschafts- und Namensrechts-Änderungsgesetz 177. §, https://www.ris.bka.gv.at/Dokumente/ BgblAuth/BGBLA_2013_I_15/BGBLA_2013_I_15.pdfsig.

${ }^{116}$ KecsKés László (szerk. GellérT György): A Polgári Törvénykönyv magyarázata (Budapest: KJKKERSZÖV 2004) 95.

${ }^{117}$ A cselekvőképességre vonatkozó magyar jogi szabályozás történeti változásainak részletes bemutatását lásd: MoLNÁR Hella: „A cselekvőképességre vonatkozó magyar szabályozás változása 65 év alatt (1952-től napjainkig)" in: VÉKÁs Lajos: Fejezetek a polgári törvénykönyv keletkezéstörténetéből (Budapest: Magyar Közlöny 2018).

${ }^{118}$ Ezek a rendelkezések a német polgári törvénykönyv (BGB) hatását tükrözik. Lásd Izsó Krisztina: „A gyermek önrendelkezése - Egy ombudsmani jelentés margójára” Magyar Jog 2019/3. 134.

${ }^{119}$ STADAT - 2.5.10. Gyermekotthonban és nevelőszülőknél ellátott gyermekek és fiatal felnőttek a gondozás időtartama szerint (2004-), https://www.ksh.hw/docs/hun/xstadat/xstadat_eves/i_ fsg009.html.

${ }^{120} \mathrm{KSH}$ Statinfo v39. 
a nevelőszülők (2014-ben 5531, 2019-ben 5515) és ezen belül a különleges nevelőszülők száma is (2014-ben: 959, 2019-ben 1135) csak kismértékben emelkedett.

Az alapvető jogok biztosa mint OPCAT nemzeti megelőző mechanizmus a Károlyi István Gyermekközpont Különleges Gyermekotthonában tett látogatásáról 2016ban közzétett jelentésében felhívta a figyelmet arra, hogy az elhelyezés megszüntetésének kiemelten fontos eleme legyen az örökbefogadás és a nevelőszülőnél történő elhelyezés elősegítése. ${ }^{121}$

A szülöi felügyelet tekintetében a 2013-as Ptk. kimondja, hogy azt a szülők egymással együttmüködve kötelesek gyakorolni, és e tekintetben jogaik és kötelezettségeik egyenlőek. ${ }^{122} \mathrm{~A}$ szülői felügyelet alatt nem álló kiskorú tekintetében a gyámrendelés korábbi szabálya kiegészült azzal, hogy az ítélőképessége birtokában lévő gyermek véleményét megfelelő súllyal kell figyelembe venni. ${ }^{123}$

\subsection{A CSELEKVÖKÉPTELEN NAGYKORÚAK}

A francia Code Civil 2009-ben módosított 433. cikke szerint a bíróság a cselekvőképesség korlátozása nélkül átmenetileg vagy bizonyos ügyletek vonatkozásában védelem alá helyezheti azokat a személyeket, akik olyan mentális vagy testi fogyatékossággal élnek, hogy az akadályozza az akaratuk kinyilvánítását. A védelem azt jelenti, hogy bizonyos ügyleteket csak egy erre felhatalmazott segítő (mandataire spécial) útján köthet meg, ennek hiányában az ügylet, a körülményeket is figyelembevéve (az ügylet hasznossága, a védendő személy vagyona, a másik fél jóhiszemüsége) értékaránytalanság esetén megtámadható, és érvénytelenné nyilvánítható. Ha ez a típusú segítség nem elegendő, állandó segítségre van szükség, az érintett személyt a bíróság curatelle vagy tutelle (a gondnokság két formája) alá helyeztheti, ez utóbbi jogintézmény továbbra is már a személy képviseletét is jelenti a jogügyletek megkötése során. A francia jogban a családtanács léte meghatározó, a bíróság a gondnokság alá helyezéssel egyidejüleg családtanácsot alakíthat, a családi körülmények és a gondnokolt kívánságának figyelembevétele alapján. A családtanács véleményét a gondnok eljárása során figyelembe kell venni, ha pedig ilyen nem került megalakításra, a nagykorúak esetében ennek szerepét a bíró tölti be.

Az osztrák ABGB szerint azon nagykorúak mellé, akik mentális fogyatékosság miatt nem tudják az ügyeiket ellátni, gondnokot (Sachwalter) kell kijelölni. A fogyatékosság mértéke szerint a Sachwalter eljárása vonatkozhat csak egyes ügyek ellátására, az ügyek meghatározott körére, vagy lehet ennél tágabb körü, minden ügyre kiterjedő is. A gondnoknak személyesen kapcsolatot kell tartania a gondnokolttal, és az ellátását is biztosítania kell. ${ }^{124}$

\footnotetext{
${ }^{121}$ AJB-331/2016. s., http://www.ajbh.hw/documents/10180/2506630/F\%C3\%B3t_KGY_06_01.pdf 108a6eb99-4261-4dd3-a9c0-90ccfdf58963.

122 2013: V. törvény a Polgári Törvénykönyvröl 4:147. §.

123 2013: V. törvény a Polgári Törvénykönyvröl 4:228. §.

${ }^{124}$ Koziol-Welser (20. lj.) 565-566.
} 
A cselekvőképtelenekről szóló szabályozás kapcsán a magyar jog vonatkozásában az 1959-es Ptk. 2001-ben történt módosításáról, a hatályba nem lépett 2009es polgári törvénykönyvről és a 2013-as Ptk. szabályairól kell szólni. A 2001-ben bevezetett szabályok lehetőséget adtak a bírónak arra, hogy a cselekvőképességet csak meghatározott ügycsoportok tekintetében korlátozza, és előirták azt is, hogy a cselekvőképességet korlátozó vagy kizáró gondnokság alá helyezést felül kell vizsgálni. A 2009-es Ptk. a nagykorú személyek döntéshozatalának segítése érdekében létrehozta az előzetes jognyilatkozat és a cselekvőképességet nem érintő, támogatott döntéshozatal intézményét. A támogatott döntéshozatal szabályairól külön törvény született, ${ }^{125}$ amely szerint - állandó jelleggel vagy olyan ügycsoportok tekintetében, amelyekre nézve a támogatott személy nem áll gondnokság alatt - a gyámhatóság a támogatott személy kérelmére vagy a bíróság megkeresése alapján támogatót rendel ki, aki tanácsaival segíti a támogatott személy döntéseit, jognyilatkozatait, eljárási cselekményeit. ${ }^{126}$ A hatályba nem lépett 2009-es Ptk. forradalmi változtatása volt továbbá - a CRPD által képviselt irányvonalnak megfelelően -, hogy a nagykorú személyek vonatkozásában csak cselekvőképességet korlátozó gondnokságot ismert, és a cselekvőképességet kizáró gondnokság kategóriáját megszüntette. A 2013-as polgári törvénykönyv az előzetes jognyilatkozat és a támogatott döntéshozatal intézményeit fenntartotta, de a gondnokság kategóriái tekintetében csak terminológiai változtatást eszközölt: a cselekvőképességet részlegesen és teljesen korlátozó gondnokságot egyaránt ismeri.

\section{KONKLÚZIÓ}

Ez a nagyobb ívű témát felölelő cím alatt megírt - és még folytatandó kutatásra szánt - tanulmány egy első áttekintést ad arról, hogy a cselekvőképtelenek - a kiskorúak, és a fogyatékosságuk miatt cselekvőképességükben korlátozott felnőttek - helyzetét tükröző jogi szabályozás hogyan alakult a XIX. század elejétől kezdődően napjainkig a vizsgált jogrendszerekben. Az egyes országok megoldásait egymás mellé állítva az adott korszak és a társadalmi-történeti adottságok függvényében hasonlóságok és lényegi különbségek egyaránt fellelhetők.

A XIX. századi paternalista családmodellnek megfelelően a kiskorú személyi és vagyoni ügyeinek rendezése tekintetében fennálló apai hatalom mindhárom jogrendszerben jellemző volt. A francia jogrendszerben az apa halála után az apai hatalom és a gyámság feladata kettéválhatott, és a gyámi feladatokat a családtanács látta el. Az osztrák és a magyar jogrendszerben az apai hatalom megszűnését követően a kiskorú gyámság alatt állt (az anyát a magyar jogban csak gyámi tisztség illette), de a vagyon kezelésének joga elválhatott a személyi felügyelettöl.

A XX. században a nemek közötti jogegyenlőség megteremtésével a szülői hatalom az anyát és az apát egyaránt megillette, és a nők cselekvőképességének kor-

${ }^{125}$ Lásd a támogatott döntéshozatalról szóló 2013. évi CLV. törvényt.

${ }^{126}$ Lásd a támogatott döntéshozatalról szóló 2013. évi CLV. törvény 2. és 4. §-ait. 
látozását is megszüntették. A „törvénytelen” gyermekek helyzete sokáig hátrányos volt a házasságban született gyermekek jogállásához képest. Változást az ipari forradalom hozott, a növekvő népesség eltartásához a gyermekmunka is hozzájárult. Az eltartásra csak az anyával (és annak rokonaival) szemben jogosult, házasságon kívül született gyermekek „megmentésére” kialakult a hivatásos gyámság intézménye és árvaházak nyíltak. A kiskorúak dolgozhattak, az önfenntartásra utalt gyermekek a keresetükkel maguk rendelkezhettek.

A testi vagy mentális fogyatékossággal élő személyek gondnokság alá helyezésére mindhárom jogrendszer lehetőséget ad. Az osztrák jogban a korlátozott cselekvőképesség intézménye később jelent meg, és a francia Code Civil rendelkezéseiben is csak a XX. század második felében történt módosítás során kristályosodott ki a gondnokság két intézményének részletes szabályozása. A gondnokság két formája mellett a francia jog ismeri a gondnokság alá helyezés nélkül történő jogi védelem biztosítását. Magyarországon is bevezették a támogatott döntéshozatal intézményét, de emellett megmaradt a gondnokság alá helyezés lehetősége is.

A XIX. század második felétől a fogyatékossággal élő felnőttkorúak intézményi elhelyezése is megindult, és fokozatosan előtérbe került a családi környezetben ellátottak számához képest. Az intézményesedés visszafordítása napjaink feladata, ami mind a kiskorúak, mind a fogyatékossággal élő nagykorúak tekintetében az erre irányuló törekvések ellenére csak kismértékben tudott megvalósulni.

A tanulmány áttekintést próbált adni a cselekvőképtelenekre vonatkozó szabályozásról, felvázolva az annak hátterét jelentő társadalmi folyamatokat az egyes országokban. Magánjogi összehasonlítást végezve és a terjedelmi korlát miatt sem tudott kitérni a témában született nemzetközi egyezmények jelentőségére, a CRPD ismertetésére és a CRPD-nak megfelelő jogi szabályozás megalkotásának fontosságára. Feladatának sokkal inkább azt tekintette, hogy tudományos háttérmunkát, adalékot adjon ehhez a feladathoz. 